\title{
제63차 OECD DAC 개발재원 통계작업반 전체회의 및 워크샵
}

\section{I . 회의개요}

제63차 $\mathrm{OECD} \mathrm{DAC}$ 개발재원 통계작업반 전체회의 및 워크샵이 2012년 6월 5일부터 8일까 지 $\mathrm{OECD}$ 본부에서 개최됨.

\section{II . 주요내용}

- 금번 워크샵과 회의에서 논의된 사항을 바탕으로 통계작업반 사무국과 국제원조투명성이 니셔티브(IATI)는 투명성 제고를 위한 부산선언 이행에 대한 문서를 작성하였으며, 원조효 과작업반(WP-EFF)에서 동 문서를 검토하여 채택 여부를 결정하기로 함.

- 구속성 원조 통계의 신뢰도 제고를 위하여 통계작업반에서는 구속성/비구속성 구분이 무 의미한 사업유형을 검토하기로 하였고 이에 한국은 '개발인식증진' 을 검토대상에 포함해 줄 것을 요청함.

- 개발관련 재원(Development Related Finance)의 중요성이 확대됨에 따라 수출신용보 고 체계 개선 및 개발관련 재원에 대한 다양한 연구 수행 등의 요구가 증대되고 있음. 이와 관련하여 금번 회의에서 독일과 네덜란드의 공동연구 결과 발표가 있었고 'Other Official Flows(OOF)' 명칭 변경에 대한 논의가 활발하게 이루어짐.

\section{III. 관찰 및 평가/건의}

- 투명성 제고를 위한 부산선언 관련문서에 대해 대부분의 회원국이 동의를 표하였고 일부국 가에 대해 사무국은 동의 여부를 조속히 서면제출해 줄 것을 요청하였는 바, 이에 대한 적 의 조치가 요구됨.

- 수정 사항 없이 동 문서가 WP-EFF 를 통과하게 될 경우, IATI 회원 가입 여부와 관 계없이 IATI 기준의 모든 항목들을 2015년까지 보고해야 하므로 국내적인 시스템 보완 등 이를 위한 대비가 필요

- 한국이 제안한 '개발인식증진' 비용이 '비구속이 불가능한 원조(not untiable aid)'로 분 류되면 비구속성 비율의 증가가 기대되는 바, 차기회의에서 해당건이 논의될 수 있도록 지 속적인 관심과 노력이 요구됨. 
- Non-ODA 통계 개선을 통해 개발관련 재원의 적절한 실적 집계 및 평가 요구가 확산되고 있으며 이는 post-MDG 논의와도 밀접한 관계가 있는바, 관련 영역에 대한 동향 파악 및 연구가 원활히 이루어질 수 있도록 지속적인 관심과 노력이 요구됨.

- 금번 회의에서 결정된 $\mathrm{ODA}$ 적격 국제기구 목록(Annex2), 기타 다자지구 채널코드 수정 사항을 국내 ODA 통계보고시스템에 반영하여 2011년 확정치 보고가 정확히 이루어질 수 있도록 점검이 요구됨. 